\title{
Rekayasa Mesin Pengaduk Untuk Pembuatan Pupuk Kandang Kotoran Sapi Guna Meningkatkan Kesejahteraan UKM Peternak Sapi
}

\author{
Suhartoyo \\ Sekolah Tinggi Teknologi Warga Surakarta, Jl Raya Solo Baki KM 2 Kwarasan,Sukoharjo, Indonesia
}

\begin{abstract}
Proses produksi pembuatan pupuk organik masih dilakukan secara manual, sehingga proses pembuatan pupuk membutuhkan waktu yang lama. Proses pencampuran bahan pupuk kandang dilakukan pengadukan dengan menggunakan cangkul sehingga bahan campuran pembuatan pupuk kandang menjadi tidak rata. Agar hasil pencampuran bahan pupuk kandang menjadi rata dan lebih efisien dalam pengerjaan maka dirancang mesin pengaduk pupuk, dan dilanjutkan pelatihan pengoperasian mesin, pelatihan perawatan mesin, dan pelatihan pengemasan produk untuk keperluan peningkatan pemasaran. Mesin pengaduk menggunakan sumber penggerak motor bakar 6 PK berbahan bakar bensin, motor bakar terhubung dengan poros pengaduk menggunakan pully dan belt. Pengaduk berputar dengan gerakan mencampur dan membalik kotoran sapi dan campurannya sehingga menghasilkan campuran pupuk organik yang mempunyai kandungan yang rata. Dengan adanya mesin pengaduk pupuk organik dan dilakukan pelatihan melalui program Kemitraan Masyarakat dapat membantu kesulitan yang dihadapi mitra sehingga dapat menaikan jumlah produksi dan dapat menambah kesejahteraan mitra.
\end{abstract}

Keywords: Pupuk organik ; mesin pengaduk; motor bakar, campuran.

\section{Introduction}

Kabupaten Karanganyar merupakan kabupaten yang strategis untuk pengembangan pertanian dan peternakan secara geografis Kabupaten Karanganyar merupakan salah satu wilayah kabupaten di Propinsi Jawa Tengah yang berbatasan dengan Kabupaten Sragen di sebelah utara, Propinsi Jawa Timur di sebelah timur, Kabupaten Wonogiri dan Sukoharjo di sebelah selatan dan Kota Surakarta dan Kabupaten Boyolali di sebelah barat. Luas wilayah Kabupaten Karanganyar adalah 77.378,64 Ha, yang terdiri dari luas tanah sawah 22.130,32 Ha dan luas tanah kering 55.248,32 Ha. Tanah sawah terdiri dari irigasi teknis 14.361,57 Ha, non teknis 6.229,28 Ha, dan tidak berpengairan 1.542,52 Ha. Kabupaten Karanganyar daerah yang sangat subur, dan banyak hewan yang diternak oleh masyarakat, ternak yang paling banyak setelah kambing dan domba adalah ternak sapi. Sapi yang di ternak adalah jenis sapi potong maupun sapi perah. Jumlah sapi yang diternak menghasilkan kotoran yang jumlahnya sangat banyak dan pemanfaatanya masih sangat sederhana. Kotoran sapi tersebut hanya digunakan untuk sebatas pupuk untuk tanaman dan sawah, belum memperhatikan faktor ekonomi dan kandungan unsur hara yang terkandung didalamnya. Satu ekor sapi bisa menghasilkan kotoran sapi sebanyak 8-10 kg / perhari (Ratriyanto et al., 2019).

Pupuk berasal dari kotoran sapi sangat banyak manfaatnya, pupuk dari kotoran sapi termasuk pupuk organik. Beberapa manfaat ketika menggunakan pupuk organik dari kotoran sapi, keuntungan tersebut antara lain adalah : Struktur tanah menjadi lebih baik, memiliki unsur hara yang sangat dibutuhkan oleh tanaman, dan banyak kandungan bahan makanan untuk mikroba yang sangat penting untuk penguraian dan menggemburkan tanah (Setyaningsih et al.,

\footnotetext{
* Corresponding author:

E-mail address: hartoyoatw91@gmail.com
} 
2019). Tetapi hal yang harus diketahui adalah kualitas kotoran sapi tergantung dari makanan sapi, dan bila daerah peternakan sapi didaerah tinggi yang lembab maka kotoran sapi akan banyak mengandung air (Melsasail dkk, 2018). Bila kotoran sapi yang banyak mengandung air tersebut dijadikan pupuk maka hasilnya adalah pupuk organik dengan kadar air tinggi, kadar air dalam pupuk organik harus diturunkan dan diperlukan peningkatan unsur hara makro sehingga pupuk organik tersebut menjadi berkualitas dan dapat memenuhi kebutuhan tumbuh bagi tanaman (Alimuddin dkk., 2020). Pemanfaatan kotoran sapi menjadi pupuk organik untuk mencukupi kebutuhan nutrisi tanaman merupakan proses yang banyak menguntungkan. Keuntungan tersebut antara lain adalah menjaga lingkungan hidup tetap asri dan terhindar dari pencemaran lingkungan akibat bau dari kotoran yang tidak terurus. Bila kotoran sapi diolah sedemikian rupa menjadi pupuk yang bernilai ekonomi maka dapat meningkatkan kesejahteraan peternak sapi (Shomad dkk ., 2017). Adanya nilai ekonomi dari pengolahan kotoran sapi menjadi pupuk organik adalah peluang bagi peternak untuk meningkatkan pendapatan secara ekonomi (Arifin dkk., 2019)

Bila menggunakan pupuk kimia secara terus menerus dan lama untuk memupuk tanaman maka tanah menjadi rusak dan tanaman tidak bisa tumbuh berkembang seperti yang diharapkan (Ratriyanto et al., 2019)(Rakhmawati dkk., 2019).

Pemanfaatan limbah kotoran sapi untuk dijadikan sebagai pupuk kandang yang mempunyai kualitas yang lebih baik dan memiliki nilai jual yang lebih tinggi merupakan kendala yang dihadapi para peternak karena belum mempunyai kemampuan memproduksi pupuk kandang tersebut dengan baik. Pupuk organik dari kotoran sapi memiliki rasio $\mathrm{C} / \mathrm{N}$ dibawah baku mutu dapat menguntungkan petani sebagai pengganti pupuk non organik (Fahrunnisa dkk., 2019). Proses pembuatan pupuk organic dengan cara pengkomposan. Pengkomposan adalah proses penurunan kandungan $\mathrm{C} / \mathrm{N}$ bahan organic menjadi setara dengan kandungan $\mathrm{C} / \mathrm{N}$ tanah humus. Pengolahan kotoran sapi menjadi pupuk organic yang kaya akan unsur N,P,K dapat memperbaiki kualitas tanah sehingga bila ditanami tanaman akan tumbuh dengan subur (Sutrisno dkk., 2019).

Proses produksi masih dilakukan di UKM mitra masih secara manual, sehingga proses pembuatan pupuk lambat. Proses pencampuran komposisi bahan pupuk kandang dilakukan dengan pengadukan dengan menggunakan cangkul sehingga kerataan bahan pupuk kandang susah untuk merata dengan baik. Untuk proses pencampuran komposisi bahan pupuk kandang tadi untuk dihasilkan campuran yang merata dan lebih efisien maka dirancang mesin untuk menyelesaikan proses pembuatan pupuk kandang. Mesin yang digunakan UKM harus digunakan oleh UKM, kunci keberhasilan tersebut adalah komunikasi dan ketersediaan sumberdaya manusia dan sumber energi yang digunakan sebagai penggerak alat (Sugiarto dkk, 2017). Hal yang perlu diperhatikan dalam pembuatan mesin untuk UKM adalah kapasitas mesin, cara pengoperasian, dan sumber energi yang digunakan untuk penggerak (Sari dkk., 2018).

Dari uraian diatas maka diperlukan mesin pengaduk untuk mempercepat proses dan hasil pengolahan pupuk yang lebih baik. Mesin pembuat pupuk organik dibuat untuk membantu pekerjaan manusia (Alimuddin dkk., 2020). Dengan kegiatan PKM bagi masyarakat dengan memberikan pendampingan pengelolaan dan alat pengaduk ini diharapkan akan meningkatkan kualitas produksi pupuk dan gilirannya meningkatkan kesejahteraan UKM.

\section{Kondisi Mitra}

UKM ini terletak Ngentak, Kecamatan Jumantono Karanganyar kurang lebih 25 km dari kampus ATW Surakarta. UKM ini letaknya strategis karena merupakan daerah yang cocok untuk mengembangkan usaha peternakan karena didukung wilayah sekelilingnya untuk penyediaan pakan ternak. UKM ini merupakan peternakan penggemukan sapi dimana memiliki 60 ekor sapi. Usaha ini selain menjual sapi hasil ternakan juga mengolah kotoran sapi menjadi pupuk. Dalam proses pembuatan pupuk dijalankan masih sangat manual dari proses persiapan sampai pembuatan masih menggunakan tenaga manusia. Menurut Bapak Joko Tri bahwa permintaan pupuk buatan UKM ini cukup banyak tapi belum dapat terpenuhi karena kapasistas produksi masih dilakukan secara manual. Bahan kotoran dari ternak sapi ini 35 kubik kotoran basah per bulan.Kondisi mitra 2 UKM ini terletak di Sedayu,Kec.Jumantono Kab. Karanganyar kurang lebih $20 \mathrm{~km}$ dari kampus ATW Surakarta. UKM ini hampir sama dengan UKM 1 letaknya strategis karena merupakan daerah yang cocok untuk mengembangkan usaha peternakan karena didukung wilayah sekelilingnya untuk penyediaan pakan ternak. Jumlah ternak yang dipelihara di peternakan ini sebanyak 30 ekor sapi.Pembuatan pupuk kandang ini memang belum menjadi usaha utama dalam peternakan ini, tetapi dengan dilakukannnya penggunaan alat untuk mengolah pupuk kandang dengan menggunakan mesin akan membantu proses pembuatan pupuk menjadi lebih cepat. Dengan demikian akan menghasilkan lebih banyak pupuk kandang yang gilirannya akan meningkatkan tambahan hasil penjualan pupuk kandang yang akan mengurangi biaya operasional sehingga keuntungan peternakan ini meningkat. 


\section{Metode}

Kegiatan pengabdian pada masyarakat yang dilakukan dengan mitra peternak sapi, dengan pemanfaatan kotoran sapi yang diolah menjadi pupuk organic diharapkan dapat meningkatkan pendapatan dari mitra. Untuk mencapai tujuan tersebut maka harus ada methode yang dilakukan, metode yang dilakukan adalah sebagai berikut :

a) Melakukan observasi di lapangan.

Observasi yang didapat bahwa penggunaan teknologi wajib dilakukan dalam proses produksi dari manual ke mesin.

b) Membuat konsep mesin yang akan dibuat

Konsep mesin yang dibuat adalah mesin yang digunakan untuk pengaduk pupuk/mixer

c) Menyiapkan kebutuhan bahan

Kebutuhan bahan antara lain mesin penggerak motor diesel,pisau mixer,besi untuk rangka,besi plat untuk output, bearing,pully dan sabuk untuk penghubung,dan cat.

d) Pembuatan mesin

Pembuatan mesin dilakukan di bengkel rekanan untuk proses machiningnya

e) Perakitan mesin

Perakitan mesin dilakukan sesuai dengan rancangan mesin yang akan di buat.

f) Uji coba mesin

Uji coba mesin dilakukan untuk menguji kelayakan mesin dan mengidentikasi kapasitas produksi mesin.

g) Serah terima mesin ke mitra

Penyerahan mesin dilakukan kepada mitra sehingga mesin dapat dilakukan untuk proses produksi.

h) Pelatihan penggunaan dan perawatan mesin

Pelatihan penggunaan agar mitra mampu mengoperasikan mesin dan mampu memperbaiki kerusakan yang terjadi pada mesin.

i) Pelatihan pengemasan dan pelabelan produk.

Pelatihan pengemasan dilakukan agar hasil produk dapat menarik perhatian konsumen dengan cara pengemasan yang baik dan pemberian label pada produk yang dipasarkan sehingga dapat menambah omset penjualan.

\section{Solusi yang ditawarkan}

Kegiatan ini memberikan penyelesaian terhadap permasalahan para peternak sapi dalam pemanfaatan limbah kotoran sapi untuk dijadikan pupuk kandang. Permasalahan di peternak adalah kualitas pupuk yang kurang baik dan proses produksi yang lambat. Dengan dirancangkan mesin pengaduk dan pembinaan pengelolaan pembuatan pupuk kandang ini akan meningkatkan produktivitas para peternak.

Adapun program yang ditawarkan adalah :

a. Mesin pengaduk pembuat pupuk kandang

Mesin tersebut dirancang dengan penggerak mesin diesel 8,5 PK. Putaran motor direduksikan dengan sistem transmisi V-belt. Putaran hasil reduksi dihitung berdasarkan perhitungan torsi yang dibutuhkan untuk proses pengadukan bahan pupuk kandang untuk dihasilkan campuran yang merata. Pengaduk dirancang dengan putaran tertentu untuk menghasilkan komposisi bahan pupuk kandang bisa tercampur secara merata.

Konstruksi rangka mesin dibuat dari baja profil L ST 37. Poros utama direncanakan dibuat dari baja ST 60. Semua komponen yang berputar ditutup, termasuk roda gila dan belt. Hal ini dilakukan untuk menjaga kemungkinan terjadinya kecelakaan selama pengoperasian mesin.

b. Pelatihan manajemen dan pembukuan

Pelatihan manajemen dan pembukuan ini dimaksudkan untuk memberikan pendampingan terhadap mitra untuk memisahkan pengeloaan adminitrasi keuangan antara penjualan ternak sapi dan pembuatan pupuk. Dengan dipisahkan pembukuan pembuatan pupuk diharapkan bisa lebih mudah untuk mengetahui keuntungan dari produksi pembuatan pupuk kandang sehingga memacu peternak untuk mengelola pembuatan pupuk menjadi lebih baik. 


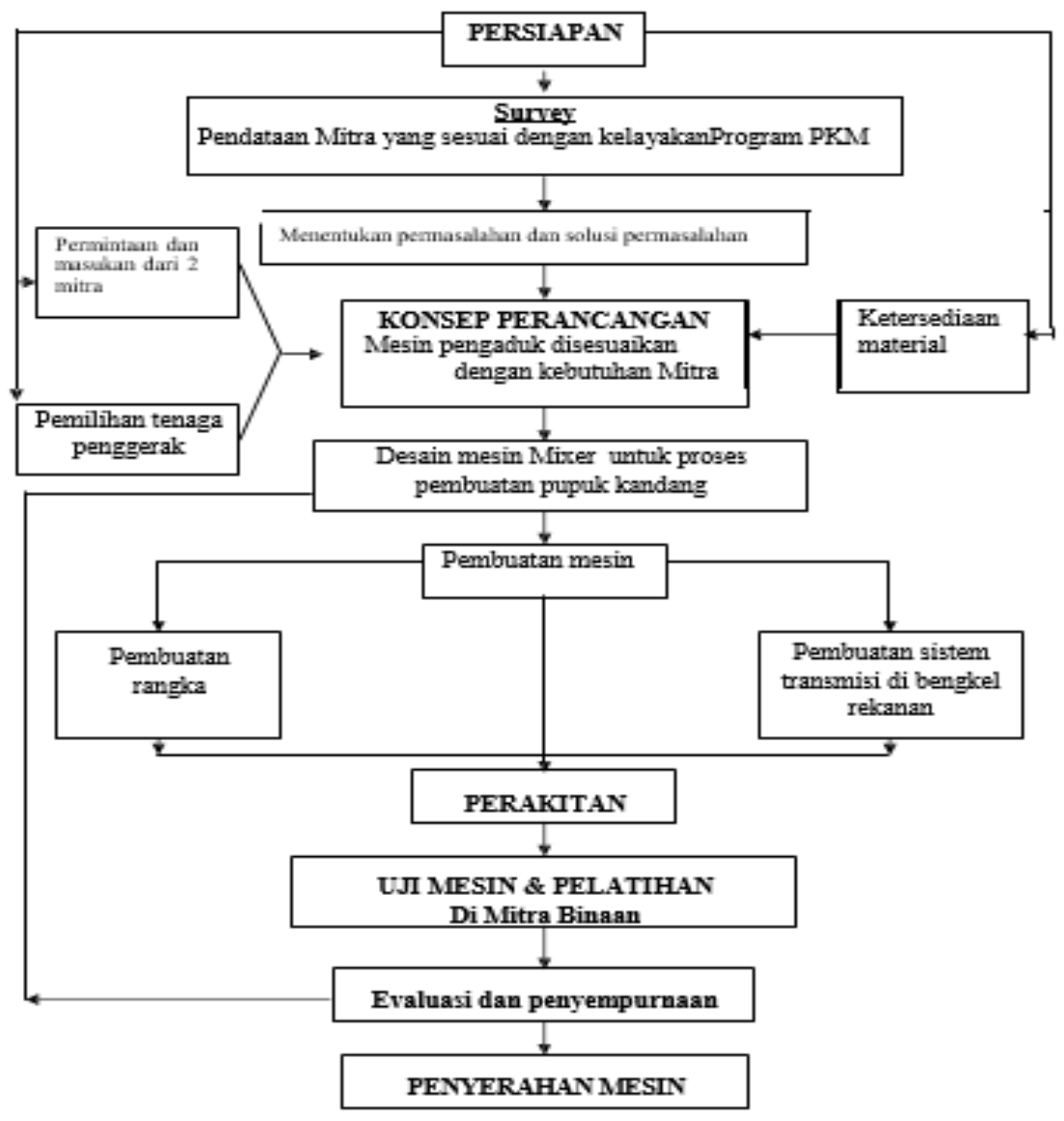

Fig. 1. Alur Pelaksanaan PKM

\section{Target Luaran}

a. Membuat mesin pengaduk yang berfungsi untuk meningkatkan proses produksi pembuatan pupuk kandang di UKM sehingga proses produksi pupuk kandang kualitasnya lebih baik.

b. Dengan adanya alat tersebut UKM akan meningkatkan dan menambah produktivitas serta pendapatan pada UKM.

c. Mampu memproduksi pupuk kandang dengan waktu yang lebih cepat dengan kualitas yang lebih baik

d. Mesin ini dalam proses pemakaiannya sangat mudah, sederhana dengan tingkat keselamatan kerja yang terjamin dan perawatannya tidak terlalu sulit. Adapun spesifikasi mesin adalah :
Panjang
: $1200 \mathrm{~mm}$
Lebar
: $700 \mathrm{~mm}$
Tinggi
: $800 \mathrm{~mm}$
Tebal plat
$: 10 \mathrm{~mm}$
Panjang bagian pemasukan : $60 \mathrm{~mm}$
Dimensi bagian pengeluaran : $40 \mathrm{~mm}$
Tenaga penggerak : : Motor Diesel 8,5 PK

\section{Tujuan}

Tujuan kegiatan ini untuk meningkatkan produktifitas peternak melalui pembuatan mesin Mixer untuk meningkatkan kualitas pupuk kandang. Dengan menggunakan mesin Mixer proses pembuatan menjadi lebih cepat dan kualitas pupuk menjadi lebih baik. 
Disamping pembuatan mesin pengaduk untuk proses produksi pupuk juga peningkatan kemampuan pengelolaan usaha sehingga usaha pembuatan pupuk ini dikelola dengan baik dan meningkatkan kesejahteraan peternak.

\section{Manfaat}

a. Potensi sosial dan ekonomi

Dengan pelaksanaan kegiatan ini akan merubah pemahaman para peternak mengenai pemanfaatn kotoran sapi yang sebelummnya hanya dianggap tidak mempunyai nilai ekonomi. Setelah dilakukan kegiatan ini pemahaman para peternak sapi terhadap limbah kotoran sapi bisa dioptimalkan untuk meningkatkan keuntungan selain dari hasil penjual ternak sapi itu sendiri. Penggunaan mesin Mixer dari kegiatan ini akan meningkatkan kualitas produksi, karena dengan menggunakan mesin proses pembuatan pupuk akan lebih cepat dan kualitas pencampuran komposisi bahan pupuk akan semakin baik dengan demikian menghasilkan pupuk yang berkualitas, sehingga nilai jual pupuk menjadi lebih mahal dan menghasilkan keuntungan yang lebih besar bagi para peternak.

b. Nilai tambah dari sisi IPTEKS

Ditinjau dari sisi iptek, terdapat tiga nilai tambah yaitu pemanfaatan teknologi tepat guna, pengenalan pada bengkel proses pembuatan mesin pengaduk pupuk organik. Desain dalam perencanaan mesin dibuat sederhana, yang utama adalah operasionalnya mudah perawatannya murah dan energy penggeraknya murah dan mudah didapat. Penggerak menggunakan motor bakar yang dihubungkan demngan poros pengaduk dengan puly dan belt, direncanakan untuk rpm rendah.

c. Dampak Penggunaan Teknologi

Dampak penggunaan teknologi adalah adanya peningkatan produktifitas UKM, evektifitas kerja dan kualitas nya lebih baik.

d. Nilai Tambah Bagi Perguruan Tinggi dan Pemerintah

Keberhasilan Pelaksana program PKM ini, dapat menjadi jembatan kerjasama antara perguruan tinggi dan beberapa industri kecil atau UKM. Pelaksanaan PKM juga merupakan bentuk peran aktif Perguruan Tinggi dalam melaksanakan Tri Dharma Perguruan Tinggi.

\section{Hasil dan Pembahasan}

a. Proses pembuatan mesin pengaduk pupuk dengan menyiapkan komponen yang diperlukan.

Proses pembuatan mesin pengaduk pupuk organik dengan membuat perencanaan mesin baik kekuatan, rpm dan kebutuhan bahan yang dibutuhkan. Termasuk didalamnya adalah pemilihan sumber penggerak yang digunakan.

Penggerak yang digunakan adalah motor bakar 6 PK berbahan bakar bensin, terhubung dengan poros dengan menggunakan puly dan belt. Pemilihan penggerak dan sumber energi yang digunakan sangat penting, karena berpengaruh terhadap cara pengoperasionalannya dan perawatan yang harus dilakukan agar mesin tersebut bisa berfungsi maksimal dan umur mesin menjadi lebih lama (Suharto, 2019). 

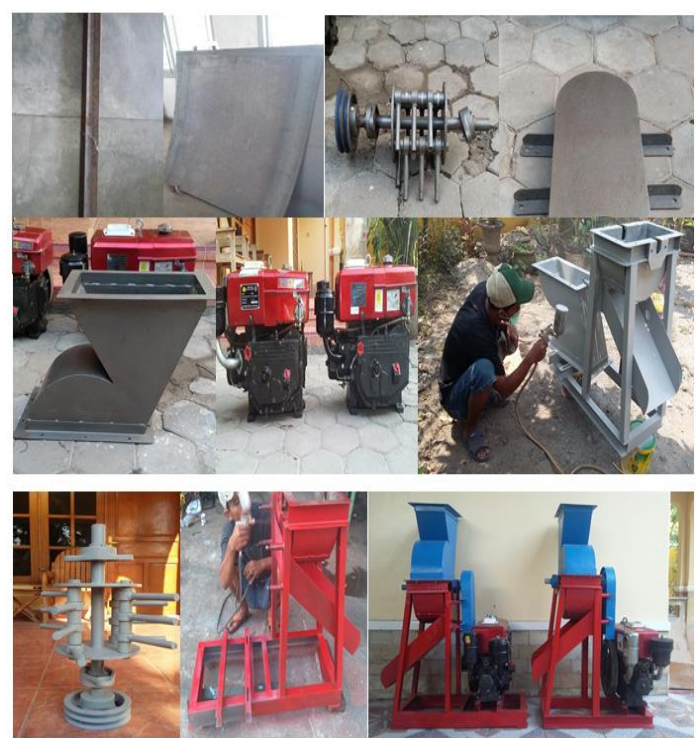

Fig. 2. Proses pembuatan mesin pengaduk pupuk organik.

b. Serah terima mesin dan uji coba penggunaan mesin.

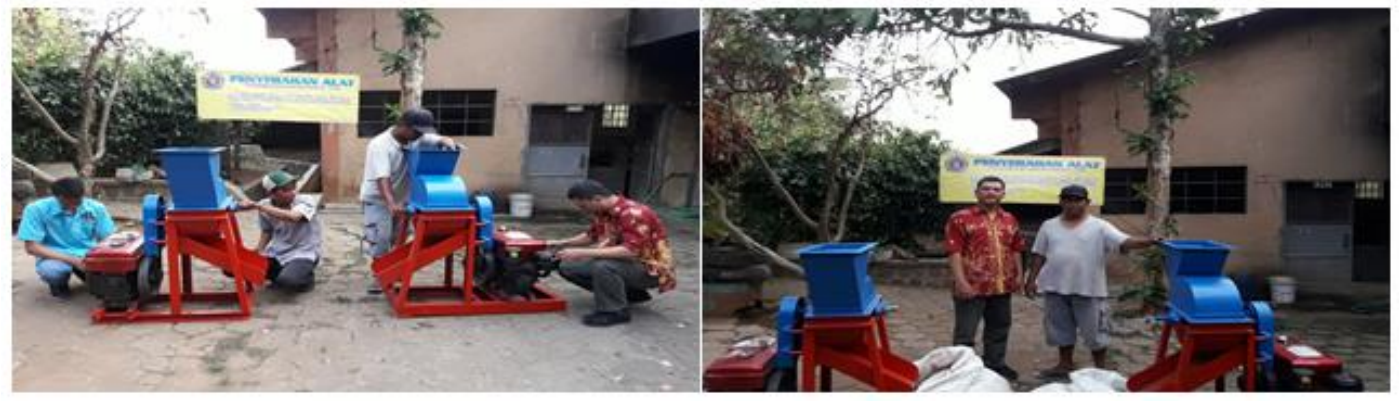

Fig. 3. Pelatihan dan penyerahan mesin pengaduk.

Setelah mesin jadi kemudian dilakukan uji coba kelayakan mesin, setelah semua dirasa berjalan normal sesuai dengan perencanaan maka dilanjutkan dengan pelatihan mengoperasikan mesin kepada UKM yang akan menggunakan. Dengan menggunakan mesin yang dirancang sedemikian rupa dari hasil diskusi dengan UKM, pengoperasin mudah dan murah. Dapat meningkatkan kinerja dan produktifitas dari UKM (Wijayanto dkk., 2018). UKM harus mendapat pelatihan penggunaan dan cara pengoperasian mesin, sehingga UKM dapat menggunakan mesin dan hasilnya bisa langsung dimanfaatkan (Elfayetti dkk ., 2017).

c. Proses Produksi pupuk dan pengemasan.

Hasil pengabdian pada masyarakat melalui Program Kesejahteraan Masyarakat (PKM) yang telah dilaksanakan bahwa proses produksi pupuk masih dilakukan secara manual, proses ini hanya mampu menghasilkan pupuk halus sebanyak $50 \mathrm{~kg} / \mathrm{jam}$.dan dikemas dalam kemasan plastik $3 \mathrm{~kg}$. sehingga sehari mitra hanya mampu menghasilkan sebanyak 16 kemasan pupuk siap jual.dengan adanya mesin pengaduk pupuk ini mitra mampu menghasilkan pupuk halus sebanyak $500 \mathrm{~kg} / \mathrm{jam}$, selama satu hari mitra melakukan proses produksi selama 5 jam sehingga menghasilkan pupuk giling sebanyak $2500 \mathrm{~kg}$. sehingga jumlah pupuk kemasan dihasilkan sebanyak 833 kemasan plastik ukuran $3 \mathrm{~kg}$. Produk UKM berupa pupuk kemasan yang dijual didaerah Karanganyar, Solo dan Sragen, yang dulunya hanya di jual masih belum diolah satu colt terbuka hanya di bayar Rp 175 000,00 sekarang dikemas dan didistribusikan omset dapat mencapai Rp 650 000,00 ribu. 


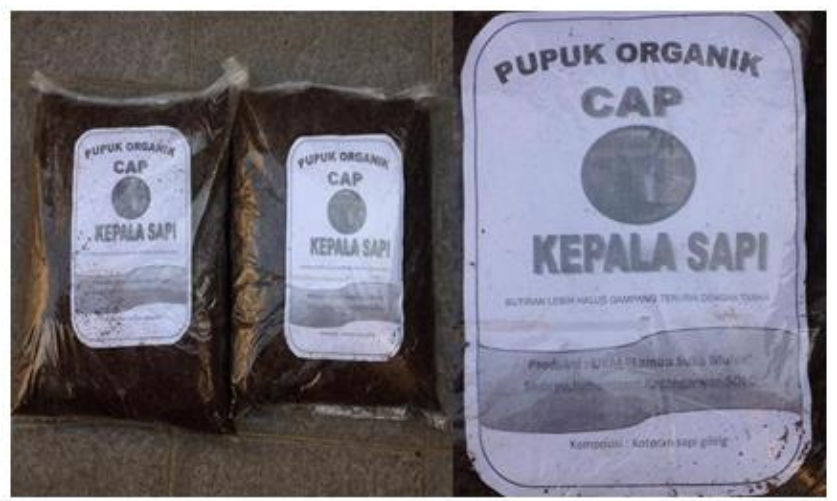

Fig. 4. Produk UKM pupuk dalam kemasan.

\section{Kesimpulan}

Proses pencampuran bahan pupuk kandang dilakukan pengadukan dengan menggunakan cangkul sehingga bahan campuran pembuatan pupuk kandang menjadi tidak rata. Agar hasil pencampuran bahan pupuk kandang menjadi rata dan lebih efisien dalam pengerjaan maka dirancang mesin pengaduk pupuk, dan dilanjutkan pelatihan pengoperasian mesin, pelatihan perawatan mesin, dan pelatihan pengemasan produk untuk keperluan peningkatan pemasaran. Mesin pengaduk menggunakan sumber penggerak motor bakar 6 PK berbahan bakar bensin . proses ini hanya mampu menghasilkan pupuk halus sebanyak $50 \mathrm{~kg} / \mathrm{jam}$.dan dikemas dalam kemasan plastik $3 \mathrm{~kg}$. sehingga sehari mitra hanya mampu menghasilkan sebanyak 16 kemasan pupuk siap jual.dengan adanya mesin pengaduk pupuk ini mitra mampu menghasilkan pupuk halus sebanyak $500 \mathrm{~kg} / \mathrm{jam}$, selama satu hari mitra melakukan proses produksi selama 5 jam sehingga menghasilkan pupuk giling sebanyak $2500 \mathrm{~kg}$. Produk UKM berupa pupuk kemasan yang dijual didaerah Karanganyar, Solo dan Sragen, yang dulunya hanya di jual masih belum diolah satu colt terbuka hanya di bayar Rp 175 000,00 sekarang dikemas dan didistribusikan omset dapat mencapai Rp 650 000,00 ribu.

\section{References}

Alimuddin, Kiswanto, M., \& Sudirman. (2020). Perencanaan Dan Pembuatan Mesin Penghancur Kotoran Sapi Dan Kambing Menjadi Pupuk Kompos Organik. Prosiding 4" Seminar Nasional Penelitian Dan Pengabdian Kepada Masyarakat 2020, 154-159.

Arifin, Z., Triyono, T., Harsito, C., Prasetyo, S. D., \& Yuniastuti, E. (2019). Pengolahan limbah kotoran sapi dan onggok pati aren menjadi pupuk organik. Prosiding SENADIMAS, January 2020, 191-196.

Elfayetti, Novira, N., Astuti, A. J. D., \& Ahsan, M. (2017). Pemanfaatan Kotoran Sapi Untuk Pembuatan Pupuk Organik Granul. Prosiding Seminar Nasional Pengabdian Masyarakat LPM UNIMED 2017, 191-193.

Fahrunnisa, F., Ratnaningsih, \& Indarawati, D. (2019). Perencanaan Unit Pengolahan Kotoran Hewan ( Kohe ) Sapi Menjadi Pupuk Organik Dengan Penambahan Bioaktivator Di Desa Cibodas Kecamatan Pasirjambu , Bandung ( Studi Kasus Di Rw 11, 12 Dan 13 Kampung. Prosiding Seminar Nasional Pembangunan Wilayah Dan Kota Berkelanjutan 2019, 227-236.

Melsasail, L., \& Kamagi, Y. E. B. (2018). Analisis Kandungan Unsur Hara Pada Kotoran Sapi Di Daerah Dataran Tinggi Dan Dataran Rendah. Agroteknologi.

Rakhmawati, D. Y., Dangga, S. A., Laela, N., \& Industri, T. (2019). Pemanfaatan kotoran sapi menjadi pupuk organik. Jurnal Abdikaarya: Jurnal Karya Pengabdian Dosen Dan Mahasiswa, 03(1), 62-67.

Ratriyanto, A., Dwi, S., Wara, W., Sigit, P. S. S., \& Widyas, N. (2019). Pembuatan Pupuk Organik dari Kotoran Ternak untuk Meningkatkan Produksi Pertanian. Jurnal Semar, 8(1), 9-13.

Sari, N., Iqbal, \& Achmad, M. (2018). Uji Kinerja Dan Analisis Biaya Mesin Pencacah Pakan Ternak ( Chopper). AgriTechno, 11(2).

Setyaningsih, I., Widad, A., Mulyati, S., \& Wahid dasa Ridwani. (2019). Pelatihan Mengolah Limbah Sapi Menjadi Pupuk Di Desa Nagasari, Kecamatan Serang Baru, Kabupaten Bekasi. Jurnal Komunitas : Jurnal Pengabdian Kepada Masyarakat, 2(1), 78-86.

Shomad, M. A., Wisnujati, A., \& Kalipucang, D. (2017). Pengelolaan Limbah Ternak Sapi Menjadi Pupuk Organik 
Komersial Di Dusun Kalipucang, Bangunjiwo, Bantul, Yogyakarta. Jurnal Berdikari, 5(1), 1-10.

Sugiarto, T., \& Sakuri. (2017). Optimasi Mesin Penghancur Kotoran Hewan Ternak Kapasitas 300 Kg/Jam Berpenggerak Motor 1,5 PK, Menggunakan V Belt. ITEKS, 9(2), 1-11.

Suharto. (2019). Pemberdayaan petani melalui rancang bangun mesin pembuat pellet kompos kotoran sapi. Jurusan Teknik Mesin Polines, 45-50.

Sutrisno, E., \& Priyambada, I. B. (2019). Pembuatan Pupuk Kompos Padat Limbah Kotoran Sapi Dengan Metoda Fermentasi Menggunakan Bioaktivator Starbio Di Desa Ujung-Ujung Kecamatan Pabelan Kabupaten Semarang. Jurnal Pasopati, 1(2), 2-5.

Wijayanto, H., Riyanto, D., Triyono, B., \& Muhammadiyah, U. (2018). Desiminasi Teknologi Mesin Pengolah Pupuk Organik Desa Jati Malang Kecamatan Arjosari Kabupaten Pacitan. Wikrama Parahita : Jurnal Pengabdian Masyarakat, 1-5. 